\title{
Dust and sandstorm: ecosystem perspectives on dryland hazards in Northeast Asia: a review
}

\author{
Sinkyu Kang ${ }^{1 *}$, Sang Hun Lee ${ }^{2}$, Nanghyun Cho ${ }^{1}$, Casmir Aggossou ${ }^{1}$ and Jungwha Chun ${ }^{3}$
}

\begin{abstract}
Background: A review of the literature was carried out to study dust and sandstorm (DSS) in terms of its ecosystem processes and relationship to other dryland disasters in Northeast Asia. Drylands are ecosystems that include grasslands, semi-deserts, and deserts, and these types of ecosystems are vulnerable due to their low primary productivity that depends on a small amount of precipitation.

Results: Drought, dust, desertification, and winter livestock disasters (called dzud) are unique natural disasters that affect the region. These disasters are related in that they share major causes, such as dryness and low vegetation cover that combine with other conditions, wind, cold waves, livestock, and land-surface energy, to dramatically impact the ecosystem.

Conclusions: The literature review in this study illustrates the macroscopic context of the spatial and temporal patterns of DSS according to geography, climate, and vegetation growth in the drylands of Northeast Asia. The effects of ocean climates and human activities were discussed to infer a possible teleconnection effect of DSS and its relations to desertification and dzud.
\end{abstract}

Keywords: Dust and sandstorm (DSS), Desertification, Dzud, Dryland hazard, Ecosystem

\section{Background}

The vast Mongolian steppe stretches far inland into Northeast Asia. The Mongolian, Kazakh-Russian, and Hungarian-Ukrainian steppes all together form the Eurasian steppe stretching from Manchuria to Hungary (Werger and van Staalduinen, 2012). Steppes are dry ecosystems that rely on a small amount of water that migrates from distant seas through cyclical precipitationevaporation processes (Dirmeyer et al. 2007; Curio et al. 2015), and these fragile ecosystems repeatedly experience desertification and rehabilitation of their grasslands, through which vegetation cover decreases and increases along with changes in the moisture content. The vegetation volume and land heat energy distribution of

\footnotetext{
* Correspondence: kangsk@kangwon.ac.kr

'Department of Environmental Science, Kangwon National University,

Chuncheon, Korea

Full list of author information is available at the end of the article
}

grasslands are closely related in that a decrease in vegetation is related to a decrease in the heat of evaporation (i.e., latent heat) and increase in heat accumulating in the ground and air, which in turn lowers the atmospheric stability and promotes the development of gusts and low-pressure air masses.

Steppe peoples have developed a plant-livestockhuman nomadic system, balancing their livelihoods and grassland sustainability (Cunliffe, 2015). Avoiding long stays in one place with dense livestock populations lowers the risk of overgrazing and desertification by giving grasslands time to recover (Zhao et al. 2005; Hoffmann et al., 2008). Although a given amount of grass is removed during grazing, livestock excrete nutrient remains after digestion to facilitate nutrient circulation in the dryland, helping new growth of grass (Biondini et al. 1998). Therefore, nomads have gathered, dispersed, migrated, and returned repeatedly according

(c) The Author(s). 2021 Open Access This article is licensed under a Creative Commons Attribution 4.0 International License, which permits use, sharing, adaptation, distribution and reproduction in any medium or format, as long as you give appropriate credit to the original author(s) and the source, provide a link to the Creative Commons licence, and indicate if changes were made. The images or other third party material in this article are included in the article's Creative Commons licence, unless indicated otherwise in a credit line to the material. If material is not included in the article's Creative Commons licence and your intended use is not permitted by statutory regulation or exceeds the permitted use, you will need to obtain permission directly from the copyright holder. To view a copy of this licence, visit http://creativecommons.org/licenses/by/4.0/. 
to changes in moisture and grassland production (Gumilev, 2009). Nomadic systems adapt to little rain and poor vegetation, and the small groups are usually scattered due to a centrifugal force to maintain a suitable distance to enable their ecological survival.

However, the tension between livelihood and conservation is often broken by internal dynamics or by natural and social forces that are exerted from the outside. Since the 1970s, the increase in cultivated land area and overpopulation of livestock in arid regions of China, including Inner Mongolia, has resulted in extensive desertification throughout the 1980s and 1990s (Zhang et al. 2003; Normile, 2007). During the socialist era, Mongolia had maintained a low livestock density without major changes, but more recently, the number of livestock has more than doubled from 25 million in 1991 to 56 million in 2015 (Eldevochir, 2016), in spite of two severe winter livestock disasters during the period.

The harsh winter climate is called 'dzud' in Mongolian ('dzhut' in Kazakh). Dzud is an extreme climatic phenomenon unique to the Central Asian steppes in the winter (Robinson and Milner-Gulland, 2003), and it is accompanied by cold waves, a frozen ground, or heavy snowfall. Sometimes, many livestock die during such winters (Sternberg, 2010; Middleton and Sternberg, 2013). In particular, if the previous summer was dry, livestock carry less fat in their body and so have a higher risk of death. Dzud, which occurs once every $4-5$ years, is a significantly adverse event for nomads who lose their means of livelihood, but it is also a natural mechanism of keeping the grassland healthy by preventing the overcrowding of sheep and goats.

In the south of the Mongolian steppe, desert ecosystems appear in the Gobi and nearby Hexi Corridor, which are also known as main sources of dust and sandstorm (DSS, popularly called 'yellow dust' in Korea) in Northeast Asia (Fig. 1). These dust sources are influenced by the conditions of multiple oceans including the Atlantic, Pacific, and Indian Oceans (Numaguti, 1999; Sato et al. 2007; Li and Ruan, 2018). In the spring of 2021, DSS occupied news headlines in China and Korea because the DSS that arrived in Korea had a high density that exceeded the warning threshold of $800 \mathrm{ug} \mathrm{m}^{-3}$ ). This was just 3 years after hopeful news in the spring of 2018 when DSS had decreased by half. This shows that the frequency and severity of DSS can vary greatly every year.

After a severe DSS event in the early 2000s, the Northeast Asia again suffered strong DSS in 2010, 2015, and 2021. It is difficult to predict DSS events in both the near and distant future because these depend on complex mechanisms that operate at various spatial and temporal scales. DSS has many similarities to other endemic dryland disasters including desertification and dzud in Northeast Asia, and these often appear in pairs rather than alone. Hence, another way to better understand DSS is to look into other dryland disasters together to comprehend their interrelationships in a climatic and ecological contexts of dryland ecosystems. Therefore, we discuss ecosystem perspectives of DSS by conducting a literature review and taking into account

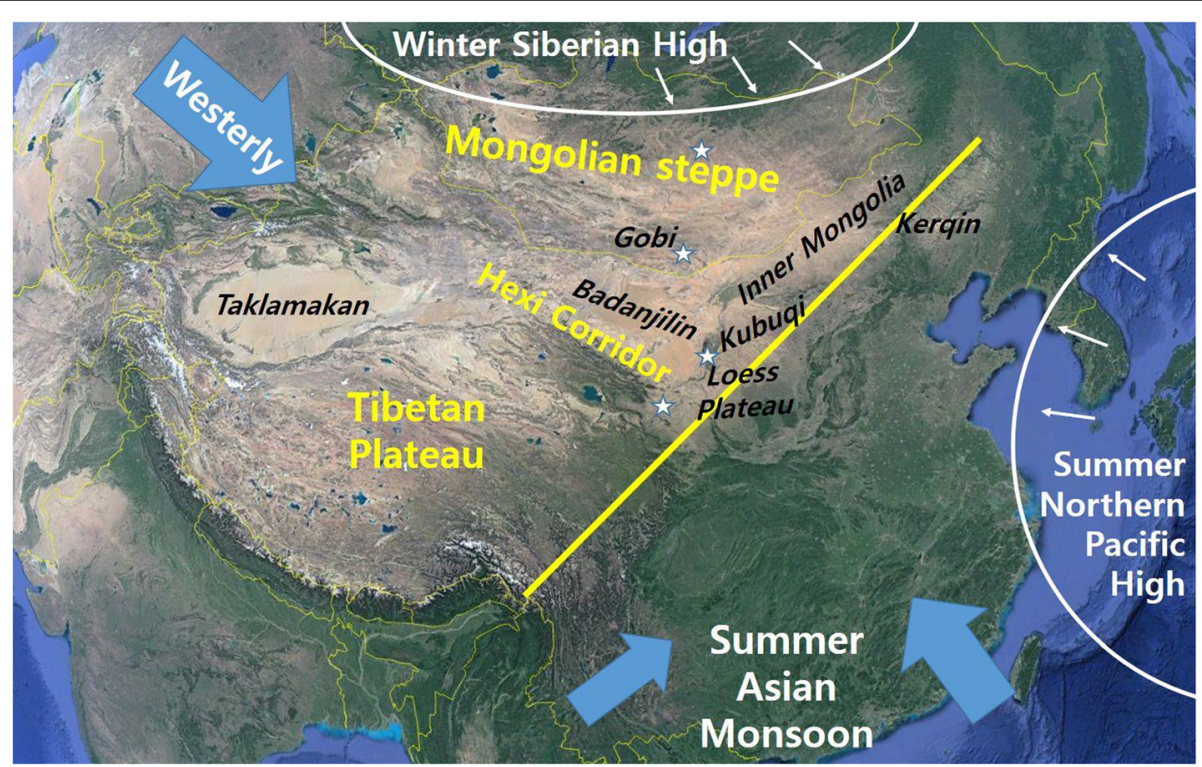

Fig. 1 A conceptual map of the geography and climate for major sources of DSS in Northeast Asia. Major sources of DSS are italicized. The straight line shows the approximate boundary of the dry area. The block arrows indicate the inflow path of moisture, and the stars are sample cities selected to demonstrate long-term climatic variability: Ulaanbaatar, Dalanzadgad, Yinchuan, and Lanzhou in the southward direction. Edited based on Google Earth map (๔ 2020 Google LCC) 
the source geography, physical and ecological process, relations with macro-scale climates such as monsoons and westerlies, and possible human impacts of dryland disasters.

\section{Source area and temporal variation of DSS}

Previous studies reported that the Gobi region, Inner Mongolian and Manchurian moving sands, deserts of the Hexi Corridor, the Loess Plateau, and the Taklamakan desert were major sources of DSS in Northeast Asia (Sun et al. 2001; Natsagdorj et al. 2003; Zhang et al. 2003; Wang et al. 2008) (Fig. 1). Among these regions, the Taklamakan desert has a low contribution to DSS reaching Korea and Japan while the deserts near the Hexi Corridor, Gobi, and Inner Mongolia have high contributions to long-distance dust reaching these countries (Kim, 2008).

Over the past few decades, DSS occurrence in dry areas in China and Mongolia has shown differences in regional changes. The importance of the Taklamakan desert and the Loess Plateau as major sources of DSS has continued to decrease. On the other hand, the Hexi Corridor and the Mongolian Plateau, which saw a temporary decrease in DSS generation in the 1980s and 1990s, became more significant sources of DSS in the 2000s. In particular, dust occurrences increased in the southeastern part of the Mongolian Plateau and in the drylands in Manchuria (Igarashi et al., 2009; Kim et al. 2010; Lee and Sohn, 2011).

Korea has received DSS through prevailing westerlies that deliver it from their sources. Since 1960, data on the occurrence of DSS in seven major cities in Korea indicates that spring DSS from March to May has accounted for $80 \%$ of the total number of days of occurrence (Fig. 2a). The annual occurrence of DSS has fluctuated for short and long cycles of 5 and 30 years, respectively. The frequency has increased from 2.6 days before 1990 to 7.1 days after 1990 (Fig. 2b). In the 2000s, when DSS was frequent, the average DSS

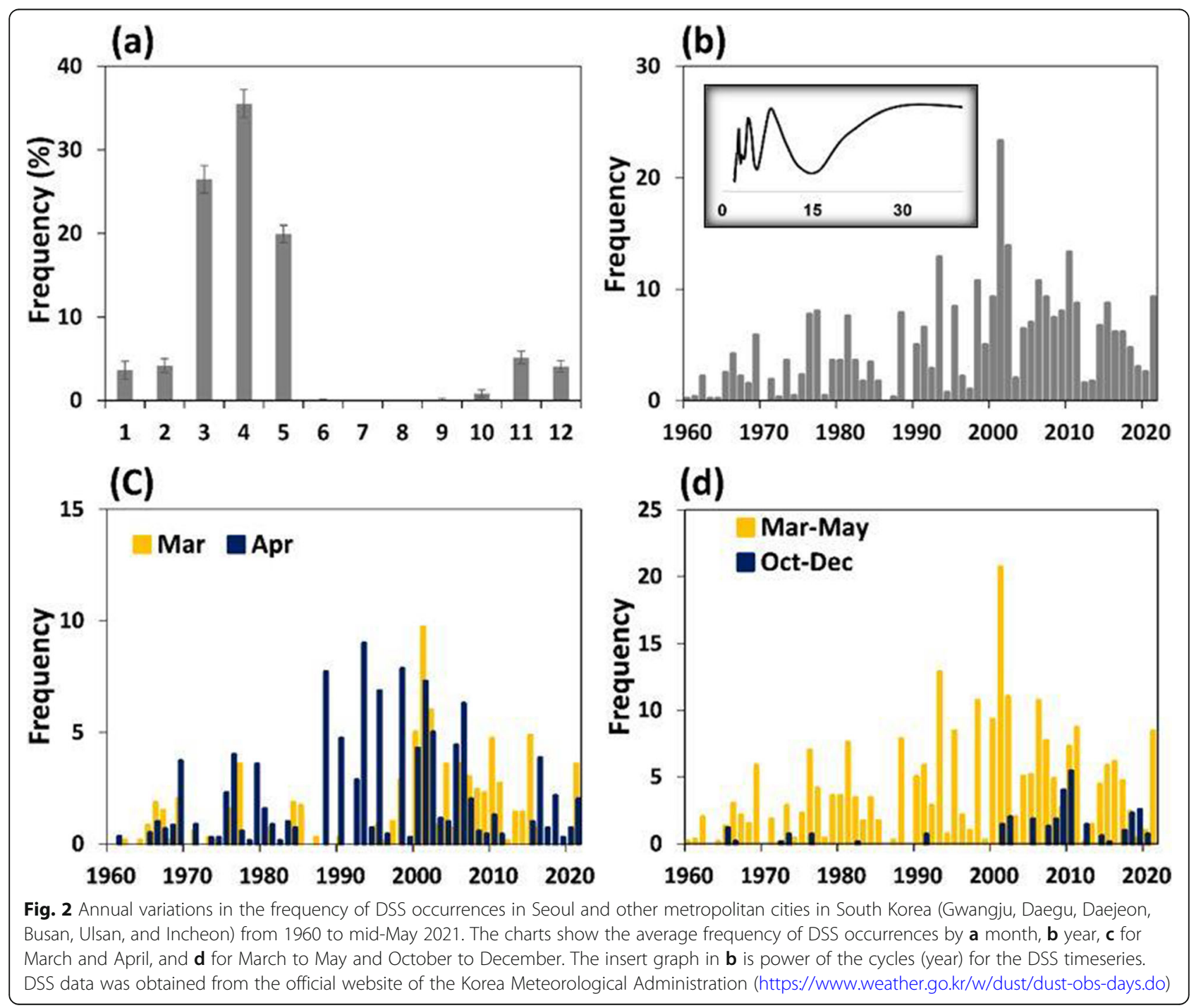


occurrence reached 9.7 days per year, but in the 2010s, it decreased to 6.1 days per year. In particular, 23 days saw a DSS occurrence in 2001, which is the second highest for Korea in modern DSS records. In the meantime, DSS started to occur earlier in the spring. DSS had been more frequent in April in the past, but in the 2000s it occurred as often in March as in April (Fig. 2c). In addition, the frequency of DSS has gradually increased in the autumn (Fig. 2d). As of May 2021, the number of DSS days for the year had reached 9.3, exceeding the average annual occurrence of 6.1 days over the past 10 years.

\section{Physical and ecological process of DSS occurrence}

DSS is a phenomenon in which sand dust is carried by winds from the ground surface to thousands of meters into the sky, to then settle over long distances around the globe. While large particles will fall near the source, fine dusts with particle sizes of 1 to $10 \mu \mathrm{m}$ can be observed in the Korean Peninsula and in Japan. The dust travels within strong westerlies in the upper atmosphere and usually arrives to the Korean Peninsula in about 2 to 3 days, and sometimes, DSS generated in Manchuria arrives within a day (Jeon et al. 2003).

Yellow sand dust only occurs when strong winds blow over dry soil and develop into an upward current as a result of a strong low pressure and a high pressure that form a pair when passing through dryland (Kim and Lee, 2013). At the boundary of the high-pressure air mass, the air moves from the high-pressure side to the lowpressure side and is bent under Coriolis forces by Earth's rotation. Thus, the wind blows in a tangential direction to the boundary between the two air masses. This area is called a trough. A greater difference in pressure produces stronger winds in the trough. When the wind speed is higher than the threshold wind speed for a dust outbreak, the dust rises to thousands of meters in the air with an ascending current of a low pressure. The then dust travels far east in the westerly wind. Strong sunlight and dry soil promote the generation of a low-pressure air mass.

Dust is easily generated in semi-deserts or desert grasslands, which are deserts with little vegetation and sparse grasslands nearby (Kimura et al. 2009). The roots of the grass and shrubs effectively hold the soil in place, and the organic matter in the soil increases the moisture retention and acts as an adhesive that binds soil particles together. Leaves and branches decrease the wind speed near the surface, stabilizing the soil so that the soil is not easily blown away. Hence, more vegetation on the ground results in a higher the minimum wind strength to generate dust (Li et al. 2020; Kimura and Shinoda, 2010). Kimura and Shinoda (2010) showed that the threshold wind speed increased exponentially as the surface vegetation cover increased.

The transpiration process of plants consumes a significant amount of radiant energy (latent heat) from the surface and contributes to improvements in the stability of the atmosphere. When there are few plants or the soil is dry, the radiant energy heats the air (producing sensible heat) rather than latent heat, causing the surface air to expand and move through buoyancy. In more severe cases, gusts and whirlwinds occur, and a large mass of low-pressure air is formed, developing a low-pressure trough.

\section{Asian monsoon, westerly, and DSS}

The straight line drawn in Fig. 1 denotes the approximate geographical boundary that separates the lowlands in the east and the highlands in the west. Major sources of DSS are concentrated between the Mongolian and Tibetan plateaus, with grasslands to the north and agricultural land and forests to the south. The boundary also roughly overlaps with the northern limit of the Asian monsoon climate, where the monsoon loses its influence (Sato et al. 2007; Chen et al. 2021).

In the summer, rain clouds develop in the western $\mathrm{Pa}$ cific and Indian Oceans, move northeast with westerly winds, and sprinkle rain in Northeast Asia (Fig. 1). The North Pacific High, which gradually becomes stronger as midsummer approaches, blocks the eastward movement of the monsoon rain clouds and pushes it northeastward. Monsoon rain clouds move farther into the continent when the North Pacific High is strong. On the other hand, monsoon rain clouds are weakened after they precipitate at the border of the plateaus, and westerly winds prevent the monsoon moisture from moving deeper to the west (Chen et al. 2021). Blocked by the plateau and the westerly, the western part of the continent has a permanent dry climate.

However, the boundary of the Asian monsoon is not permanently fixed and has been incessantly moving on a time scale of thousands of years. Around $6000 \mathrm{BC}$, during the Holocene Optimum, the Earth was hotter than it is today, and strong supermonsoons frequently occurred in equatorial waters, dropping rains farther inland (Wang et al. 2005). The dryland had shrunk during this time, but the monsoon then weakened and the drylands expanded eastward as solar energy capture decreased. Even after the beginning of the human history, there have been natural climate cycles of warming and cooling that lead to repeated movement of the boundaries of dryland until today. The rise of the nomadic empires in Northeast Asia largely coincided with the retreat of the drylands due to a mild and humid climate (Cunliffe, 2015). 
Where does the rain that falls on dryland in Northeast Asia originate from? Moisture originated from the Pacific Ocean flows westward to the dryland against westerly winds, entangled in the whirlpools of high and low pressures that occur, to then migrate and disappear in mid-latitude Northeast Asia (Sato et al. 2007; Sun et al. 2015). A small amount of rain clouds from the Indian Ocean monsoon pass over the Himalayas or bypasses the eastern end of the mountain range to deliver moisture to the Tibetan Plateau, and then the moisture moves to the Badanjilin and Gobi regions while repeating the evaporation and precipitation cycle (Numaguti, 1999; Bothe et al. 2012).

Despite its remote location, the Atlantic Ocean is as important as a source of moisture as the Pacific Ocean. With the aid of westerly winds, moisture from the Atlantic Ocean moves as far east as Siberia and the drylands of East Asia (Numaguti, 1999; Sato et al. 2007). Most drylands in Mongolia and western China are highly dependent on the moisture from the Atlantic that migrates from west to east through repeated precipitation and evaporation (Koster et al. 2004; Linderholm et al. 2011; Bothe et al. 2012; Li and Ruan, 2018).

Large high- and low-pressure air masses form yearround in the mid- and high-latitudes of the North Atlantic, and these are referred to as the Azores High and the Icelandic Low, respectively. A strong pressure trough is created between them, and many rain clouds are shot up toward Europe, like shooting an arrow (Dong et al. 2013). This trough moves north in summer when the Azores High expands and south in winter when it weakens, and it precipitates in northern Europe in the summer and central Europe in the winter (Linderholm et al. 2011; Blade et al. 2012). Parts of these rain clouds move eastward toward Siberia and Eastern Europe, transferring moisture to the drylands in Mongolia and China (Li and Ruan, 2018). Moisture wanders in a complex manner as it is entrapped by several high- and lowpressure vortices that are encountered along the way. In spite of the complex dynamic movement, a pattern of moisture inflow to Mongolia and China via west Siberia can be clearly identified when looking at the general moisture migration path over several decades (Bothe et al., 2012). On the other hand, the contribution of the Mediterranean Sea to the dryland of Northeast Asia is negligible since it is limited to the southern part of Central Asia (Numaguti, 1999).

The major sources of DSS in Northeast Asia are located at the margin of the Atlantic, Pacific, and Indian Oceans where their influence is limited. Rain clouds from the three seas bring moisture to the deserts and grasslands deep inland, and this pattern in which the ocean and land influence each other across a long distance is called teleconnection ( $\mathrm{Li}$ and Ruan, 2018). The fact that the ocean climate has certain correlations with variability in the land climate across Eurasia (Linderholm et al. 2011) suggests that the climate of Northeast Asia drylands is affected by ocean climate periodicity, such as with El Niño/La Niña in the Pacific (El Niño-Southern Oscillation, ENSO), Atlantic Multidecadal Oscillation (AMO), and Pacific Decadal Oscillation (PDO). Accordingly, changes in desertification and DSS outbreaks may be related to changes in the ocean climate, and scientific evaluations are currently underway to this effect.

Potential teleconnections have been demonstrated between drylands and ocean climates in the periodicity of interannual precipitation variations for Northeast Asia over the past 80 years (data from 1940 to 2020) (Fig. 3). Ulaanbaatar and Dalanzadgad in Mongolia and Yinchuan and Lanzhou in China are respectively located in the north and south of the Gobi Region, as show in Fig. 1. Precipitation of the former two cities varied with a prevailing periodicity over 20 years, and this stands in contrast with a strong periodicity of less than 5 years at Yinchuan and Lanzhou. It seems that those periodic changes control the temporal variability of the dust occurrence in the source regions, and this results in a more complex periodicity containing both short and long cycles for DSS arriving in Korea (Fig. 2b). Furthermore, Fig. 3 indicates that warming trends since 1970 could reinforce frequent severe droughts by enhancing evaporative water loss.

\section{Human activity, DSS, and other dryland disasters}

Along with natural factors, human activities also influence the occurrence of DSS (Kang, 2012). Excessive livestock farming, inadequate cultivation in dry land, and expansive mining activities reduce vegetation cover and groundwater, leading to desertification (Xu, 2006). However, desertification only implies an expansion of the source of DSS, and the aforementioned natural conditions must also be met for DSS events to occur. In this regard, climate change may play a more decisive role in the occurrence of DSS than anthropogenic desertification (Zhang et al. 2003; Wang et al., 2006). Investigators have observed that despite rapid desertification, dust generation in China's dry land in the 1980s and 1990s continued to decrease due to a reduced wind speed.

Anthropogenic desertification is a phenomenon in which non-desert places are turned into deserts due to anthropogenic reasons alone or together with natural factors ( $\mathrm{Li}$ et al. 2000; Zhao et al. 2005; Qi et al. 2012), and desertification increases the likelihood of DSS events. A reduction in vegetation cover accompanies desertification, which in turn lowers the threshold wind speed for a DSS outbreak (Kimura and Shinoda, 2010) and promotes the development of local gusts by destabilizing the atmosphere due to an increase in sensible 


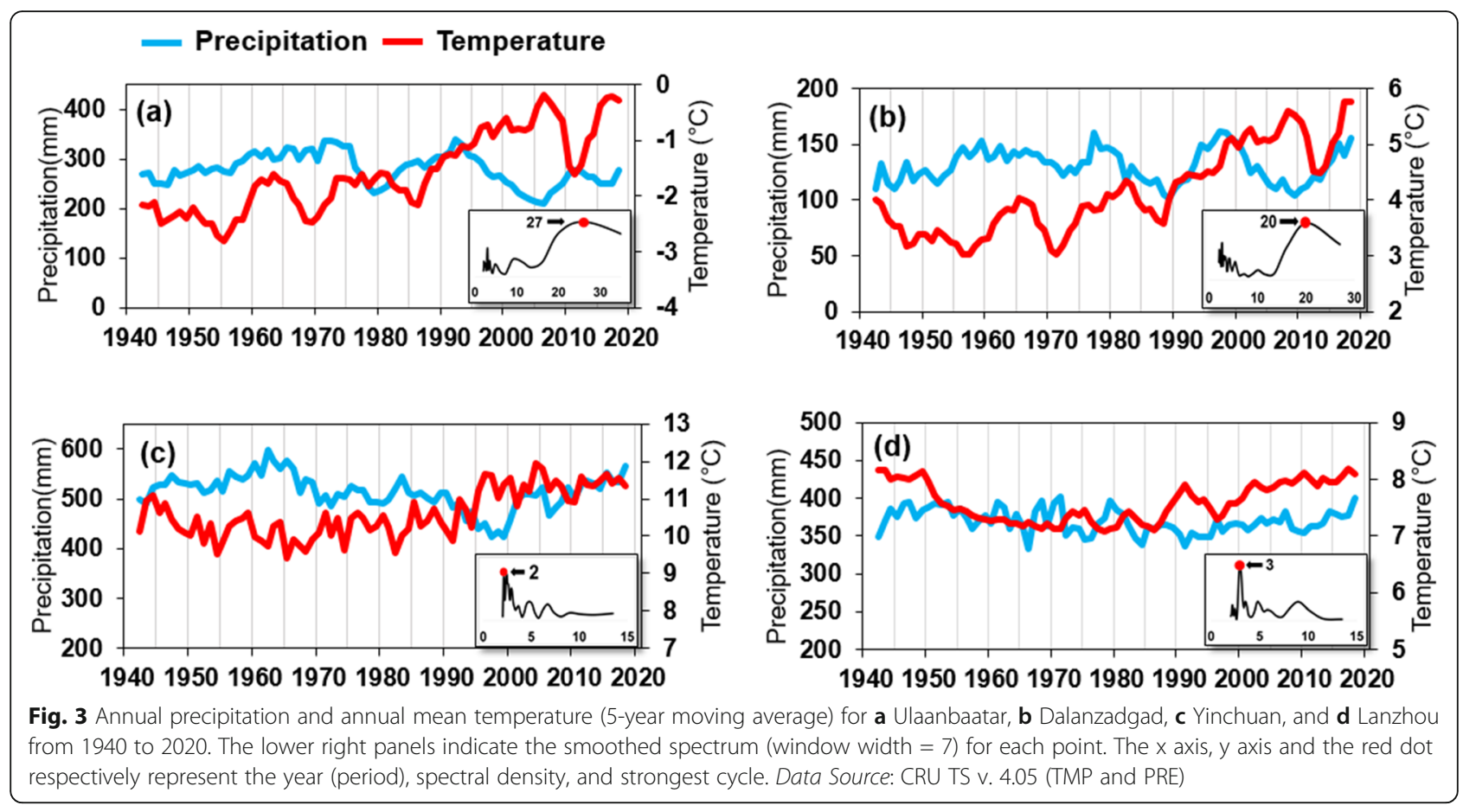

heat (Li et al. 2000). Furthermore, DSS blows the surface soil away, engaging a positive feedback loop in which desertification of nearby grasslands is further accelerated (Xu, 2006).

Chen et al. (2020) studied the expansion and decline of settled areas in the Ordos Plateau of Inner Mongolia (the bend of the Yellow River including the Kubuqi Desert in Fig. 1). They compared historical records complied over the past 2000 years to the change in soil composition according to depth of lake soil core samples. The results indicated that a lot of DSS had been generated when residence had expanded and that the period of the habitat expansion coincided with a period when Asian monsoons became stronger and moisture moved further to the north, that is, when the climate was favorable to vegetation growth on the Ordos Plateau. This study indicates that human impact overwhelmed the natural process that generates DSS since a thousand years ago.

Pastoral farming is an old human activity in the Eurasian steppe. Livestock lowers the threshold wind speed by making the grass short and sparse, and the reduction in plants decreases latent heat while increasing sensible heat, heating the surface air and generating gusts. As such, livestock has an inherent potential to promote desertification and DSS generation ( $\mathrm{Li}$ et al. 2000). When livestock are raised densely in a small area in a dryland, it causes serious damage to the grassland vegetation, resulting in desertification (Zhao et al. 2005; Huffmann et al. 2008).

Extensive desertification occurred in the 1980s and 1990s due to increased conversion to agricultural land and over-exploitation of arid regions in China, including Inner Mongolia (Zhang et al. 2003; Normile, 2007). Then, in the 2000s, a severe drought generated powerful DSS events. After 20 years of efforts to prevent desertification, the vegetation cover has increased in some areas, such as in the plains of northern China (Wang et al. 2015). However, the signs of a recovery remain uncertain in the dry grasslands of Inner Mongolia (Kang et al. 2020).

As mentioned earlier, livestock has also begun to increase rapidly in Mongolia after 1991, when livestock was privatized and Mongolia transitioned to a market economy (Eldevochir, 2016). As cashmere became a major income source for nomads, the number of goats increased significantly. Grasslands near cities are already undergoing overgrazing and desertification, and there are various opinions on whether grazing will lead to, or has already caused, vast desertification of the grassland (Dietz et al. 2005; Johnson et al. 2006). In the past 30 years, there has been a pattern of recovery after desertification in the grasslands of central and eastern Mongolia, and this change has a statistically significant correlation with changes in precipitation in this region (Kang et al. 2020). Although this correlation does not imply a causal relationship, it leads to questioning the myth that overgrazing is the main cause of desertification in Mongolia's grasslands.

Mongolia experienced severe dzud disasters in 20002002 and 2009-2010, in which about 30\% of all livestock died (Sternberg, 2010), and this period coincides with recent years of severe DSS. Dzud refers to an extreme 
winter cold and heavy snow, but the impact on livestock is greater when the summer drought and winter dzud occur together. The dzud disaster has traditionally been an ecological control mechanism of nature to prevent the overgrazing of livestock that is then followed by an expansion in desertification. Damage from a recent dzud shows that Mongolia's livestock industry still retains its old nomadic tradition, the archetype of the ecological food chain of climate-vegetation-livestock. However, the dzud induces various social problems, such as the deterioration of the livelihood of nomads, the migration of environmental refugees to the city, the inequality between the rich and the poor, and the deepening of environmental problems in the city. As such, countermeasures are necessary for adaptation and prevention (FernandezGimenez et al. 2015).

There are some cases in which policy intervention has prevented desertification and restored vegetation (Qi et al. 2012; Zhang et al. 2014), and these cases exemplify how human intervention can reverse desertification just as human activities can cause desertification. Nevertheless, human intervention to mitigate natural disasters in drylands, including proposed remedies for desertification and DSS, have been controversial due to the difficulty in proving the causal relationship between mitigation efforts and their results (Cortner, 1989) and partly because of the uncertainty in the pattern of changes in drylands at different spatial scales (Sterk and Stoorvogel, 2020). The policy measures to reduce DSS focus mostly on restoring vegetation cover, among the aforementioned conditions, to prevent DSS outbreaks, while other conditions are almost impossible to control. It is difficult to single out the direct results of the efforts to reduce DSS, and the performance of restoration programs is evaluated indirectly using a model (Guo et al. 2008).

\section{Climate change and DSS}

The geography, climate, and vegetation of the dryland in Northeast Asia explain the macroscopic context of the sources and the timing of DSS, in which a global-scale teleconnection mechanism might be involved. The changing climate will bring about various changes in climate, meteorology, and human activities in the dryland of Northeast Asia in the future, and DSS patterns will also change.

An increase in the spring temperature may lead to an earlier occurrence of DSS, and changes in the seasonality and strength of the Siberian High may increase the autumn DSS outbreaks and cause changes in the spring weather conditions and instances of DSS events ( $\mathrm{Li}$ et al. 2020). Intensification of the ENSO phenomenon can decrease the stability of the ecosystem in Northeast Asia by increasing the range of the fluctuations in drought and wet conditions in the dryland. The decrease in the
Arctic ice can increase the likelihood of heat and cold waves in mid-latitude regions, which adversely affect the growth of vegetation and livestock (Matsumura and Kosaka, 2019).

\section{Conclusions}

Desertification, DSS, and dzud disasters in dry areas in Northeast Asia are the result of various combinations of common factors, such as drought and reduction in vegetation cover, combined with additional factors, such as wind and air pressure, livestock presence, cold waves, etc. Among them, climate factors are affected by the ocean-land air flow, and thus are subordinated to the global-scale energy cycle. The inference is that DSS, vegetation growth, and desertification are not free from the long and short cycles of climate fluctuations in the ocean on the scale of several years to several decades. This leads to further evaluation of the cross-scale interactions between macroscopic and microscopic phenomena according to the variability of moisture influx to drylands through atmospheric circulation processes and adaptation mechanisms of dryland vegetation communities to the endemic climatic variability.

\section{Abbreviations \\ AMO: Atlantic Multidecadal Oscillation; DSS: Dust and sandstorm; ENSO: El Niño-Southern Oscillation; PDO: Pacific Decadal Oscillation}

\section{Acknowledgements}

This work was funded by National Institute of Forest Science, Grant number (FM0103-2021-02) and Korea Environment Institute.

\section{Authors' contributions}

SK designed this study and wrote the manuscript. ShL participated in writing, NC and CA analyzed the DSS and climate data. JC participated in the design and funding of the study. All authors read and approved the final manuscript.

\section{Funding}

There are no financial conflicts of interest to disclose.

Availability of data and materials

The datasets generated during and/or analyzed during the current study are available from the corresponding author on request.

\section{Declarations}

Ethics approval and consent to participate Not applicable.

\section{Consent for publication}

Not applicable.

\section{Competing interests}

The authors declare that they have no competing interests.

\section{Author details}

'Department of Environmental Science, Kangwon National University, Chuncheon, Korea. ${ }^{2}$ Center for Global Cooperation, Korea Environment Institute, Sejong, Korea. ${ }^{3}$ Forest ICT Research Center, National Institute of Forest Science, Seoul, Korea. 
Received: 23 September 2021 Accepted: 4 November 2021

Published online: 26 November 2021

\section{References}

Biondini ME, Patton BD, Nyren PE. Grazing intensity and ecosystem processes in a northern mixed-grass prairie. USA Ecol App. 1998;8(2):469-79. https://doi. org/10.1890/1051-0761(1998)008[0469:GIAEPI]2.0.CO;2.

Blade I, Liebmann B, Fortuny D, van Oldenborgh GJ. Observed and simulated impacts of the summer NAO in Europe: implications for projected drying in the Mediterranean region. Climatic Dynamics. 2012;39(3-4):709-27. https:// doi.org/10.1007/s00382-011-1195-x.

Bothe O, Fraedrich K, Zhu X. Precipitation climate of Central Asia and the largescale atmospheric circulation. Theor App Climatol. 2012;108(3-4):345-54. https://doi.org/10.1007/s00704-011-0537-2.

Chen F, Chen S, Zhang X, Chen J, Wang X, Gowan EJ, Qiang M, Dong G, Wang Z, Li Y, Xu Q, Xu Y, Smol JP, Liu J. Asian dust-storm activity dominated by Chinese dynasty changes since 2000 BP. Nat Commun. 2020;11:992. https:// doi.org/10.1038/s41467-020-14765-4.

Chen J, Huang W, Feng S, Zhang Q, Kuang X, Chen J, et al. The modulation of westerlies-monsoon interaction on climate over the monsoon boundary zone in East Asia. Int J Climatol. 2021;41(Suppl. 1):E3049-64. https://doi.org/1 $0.1002 / j o c .6903$

Cortner HJ. Desertification and the political agenda. Population Environ. 1989; 11(1):31-41. https://doi.org/10.1007/BF01255656.

Cunliffe B. By steppe, desert, and ocean: the birth of Eurasia. UK: Oxford University Press; 2015

Curio J, Maussion F, Scherere DA. 12-year high-resolution climatology of atmospheric water transport over the Tibetan Plateau. Earth Syst Dynam. 2015;6(1):109-24. https://doi.org/10.5194/esd-6-109-2015.

Dietz AJ, Amgalan E, Erdenechuluun T, Hess S. Carrying capacity dynamics, livestock commercialization and land degradation in Mongolia's free market era. The Netherlands: PREM, Institute for Environmental Studies, Vrije University, Amsterdam; 2005

Dirmeyer PA, Brubaker KL. Characterization of the global hydrological cycle from a back-trajectory analysis of atmospheric water vapor. J Hydrometeorol. 2007; 8(1):20-37. https://doi.org/10.1175/JHM557.1.

Dong B, Sutton RT, Woollings T, Hodges K. Variability of the North Atlantic summer storm track: mechanisms and impacts on European climate. Environ Res Lett. 2013:8(3):034037. https://doi.org/10.1088/1748-9326/8/3/034037.

Eldevochir, E.: Livestock statistics in Mongolia. FAO Asia and Pacific Commission on Agricultural Statistics, 16, 6.3 .5 (2016)

Fernandez-Gimenez ME, Batkhishig B, Batbuyan B, Ulambayar T. Lessons from the Dzud: Community-Based Rangeland Management Increases the Adaptive Capacity of Mongolian Herders to Winter Disasters. World Dev. 2015;68:4865. https://doi.org/10.1016/j.worlddev.2014.11.015.

Gumilev LN. Searching for an imaginary kingdom. Cambridge: Cambridge University Press; 2009.

Guo Z, Ai N, Polenske KR. Evaluating environmental and economic benefits of yellow dust storm-related policies in north China. Int J Sustain Dev World Ecol. 2008;15(5):457-70. https://doi.org/10.3843/SusDev.15.5:7.

Hoffmann C, Funk R, Li Y, Michael S. Effect of grazing on wind driven carbon and nitrogen ratios in the grasslands of Inner Mongolia. Catena. 2008;75(2):18290. https://doi.org/10.1016/j.catena.2008.06.003.

Igarashi $Y$, Inomata $Y$, Aoyama M, Hirose $K$, Takahashi H, Shinoda Y, et al. Possible change in Asian dust source suggested by atmospheric anthropogenic radionuclides during the 2000s. Atmos Environ. 2009;43(18):2971-80. https:// doi.org/10.1016/j.atmosenv.2009.02.018

Johnson DA, Sheehy DP, Miller D, Damiran D. Mongolian rangelands in transition. Sècheresse. 2006:17:133-41.

Kang, S.: Climatic and socio-ecological considerations on Yellow Dust and desertification in dryland regions of the Northeast Asia. Korean Journal of Nature Conservation, 6, 1-8 (2012) (written in Korean with English abstract and figure legends)

Kang W, Kang S, Liu S, Han Y. Assessing the degree of land degradation and rehabilitation in the Northeast Asia dryland region using net primary productivity and water use efficiency. Land Degradation \& Development. 2020;31(8). https://doi.org/10.1002/ldr.3506.

Kim J. Transport routes and source regions of Asian dust observed in Korea during the past 40 years (1965- 2004). Atmos Environ. 2008:42(19):4778-89. https://doi.org/10.1016/j.atmosenv.2008.01.040.
Kim S, Chun Y, Kim S-B. The features of Asian Dust events originated in Manchuria. Atmosphere. 2010;20:273-86 written in Korean with English abstracts and figure legends.

Kim S, Lee S. The analysis of the weather characteristics by source regions of the Asian Dust observed in South Korea. J Korean Geograp Soc. 2013;48:167-83 written in Korean with English abstracts and figure legends.

Kimura R, Bai L, Wang J. Relationships among dust outbreaks, vegetation cover, and surface soil water content on the Loess Plateau of China, 1999-2000. Catena. 2009;77(3):292-6. https://doi.org/10.1016/j.catena.2009.02.016.

Kimura R, Shinoda M. Spatial distribution of threshold wind speeds for dust outbreaks in northeast Asia. Geomorphology. 2010;114(3):319-25. https://doi. org/10.1016/j.geomorph.2009.07.014

Koster RD, Dirmeyer PA, Guo A, et al. Regions of strong coupling between soil moisture and precipitation. Science. 2004;305(5687):1138-40. https://doi.org/1 $0.1126 /$ science.1100217

Lee EH, Sohn BJ. Recent increasing trend in dust frequency over Mongolia and Inner Mongolia regions and its association with climate and surface condition change. Atmos Environ. 2011;45(27):4611-6. https://doi.org/10.101 6/j.atmosenv.2011.05.065.

Li B, Li Y, Chen Y, Zhang B, Shi X. Recent fall Eurasian cooling linked to North Pacific sea surface temperatures and a strengthening Siberian high. Nat Commun. 2020;11(1):5202. https://doi.org/10.1038/s41467-020-19014-2.

Li J, Ruan C. The North Atlantic-Eurasian teleconnection in summer and its effects on Eurasian climates. Environ Res Lett. 2018;13(12):129501. https://doi.org/1 0.1088/1748-9326/aaeb56

Linderholm HW, Ou T, Jeong J, Folland CK, Gong D, Liu H, et al. Interannual teleconnections between the summer North Atlantic Oscillation and the East Asian summer monsoon. J Geophys Res. 2011;116. https://doi.org/10.1029/2 010JD015235.

Matsumura S, Kosaka Y. Arctic-Eurasian climate linkage induced by tropical ocean variability. Nat Commun. 2019;10(1):3441. https://doi.org/10.1038/s414 67-019-11359-7.

Middleton NJ, Sternberg T. Climate hazards in drylands: A review. Earth-Science Rev. 2013;126:48-57.

Natsagdorj L, Jugder D, Chung YS. Analysis of dust storms observed in Mongolia during 1937-1999. Atmos Environ. 2003;37(9-10):1401-11. https://doi.org/10.1 016/S1352-2310(02)01023-3

Normile D. Getting at the roots of killer dust storms. Science. 2007:317(5836):3146. https://doi.org/10.1126/science.317.5836.314.

Numaguti A. Origin and recycling processes of precipitation water over the Eurasian continent: Experiments using an atmospheric general circulation model. J Geophys Res. 1999;104(D2):1957-72. https://doi.org/10.1029/1 998JD200026.

Qi Y, Chang Q, Jia K, Liu M, Liu J, Chen T. Temporal-spatial variability of desertification in an agro-pastoral transitional zone of northern Shaanxi province, China. Catena. 2012;88(1):37-45. https://doi.org/10.1016/j.catena.2 011.08.003.

Robinson S, Milner-Gulland EJ. Political change and factors limiting numbers of wild and domestic ungulate in Kazakhstan. Hum Ecol. 2003:31(1):87-110. https://doi.org/10.1023/A:1022834224257

Sato T, Tsujimura M, Yamanaka T, Iwasaki H, Sugimoto A, Sugita M, Kimura F, Davaa G, Oyunbaatar D. Water sources in semiarid northeast Asia as revealed by field observations and isotope transport model. J Geophys Res. 2007:112. https://doi.org/10.1029/2006JD008321.

Sterk G, Stoorvogel JJ. Desertification-scientific versus political realities. Land. 2020;9(5):156. https://doi.org/10.3390/land9050156.

Sternberg T. Unravelling Mongolia's extreme winter disaster of 2010. Nomadic Peoples. 2010;14(1):72-86. https://doi.org/10.3167/np.2010.140105.

Sun C, Li J, Zhao S. Remote influence of Atlantic multidecadal variability on Siberian warm season precipitation. Sci Rep. 2015;5(1). https://doi.org/10.103 8/srep16853.

Sun J, Ahang M, Liu T. Spatial and temporal characteristics of dust storms in China and its surrounding regions, 1960-1999: Relations to source area and climate. J Geophys Res. 2001;106(D10):10325-34. https://doi.org/10.1029/2 000JD900665.

Wang $T$, Xue $X$, Zhou L, Guo J. Combating aeolian desertification in northern China. Land Degrad Dev. 2015;26(2):118-32. https://doi.org/10.1002/ldr.2190.

Wang $X$, Chen F, Dong Z. The relative role of climatic and human factors in desertification in semiarid China. Glob Environ Chang. 2006;16(1):48-57. https://doi.org/10.1016/j.gloenvcha.2005.06.006 
Wang Y, Cheng H, Edwards RL, He Y, Kong X, An Z, et al. The Holocene Asian Monsoon: Links to Solar Changes and North Atlantic Climate. Science. 2005; 308(5723):854-7. https://doi.org/10.1126/science.1106296.

Wang Z, Huang J, Ji M, Higuchi K. Variability of East Asia dust events and their long-term trend. Atmos Environ. 2008;42(13):3156-65. https://doi.org/10.101 6/j.atmosenv.2007.07.046.

Werger MJA, van Staalduinen MA. Eurasian steppes - ecological problems and livelihoods in a changing world. London: Springer; 2012.

$\mathrm{Xu}$ J. Sand-dust storms in and around the Ordos Plateau of China as influenced by land use change and desertification. Catena. 2006;65(3):297-84. https:// doi.org/10.1016/..catena.2005.12.006.

Zhang J, Niu J, Buyantuev A, Wu J. A multilevel analysis of effects of land use policy on land-cover change and local land use decisions. J Arid Environ 2014;108:19-28. https://doi.org/10.1016/j.jaridenv.2014.04.006.

Zhang XY, Gong SL, Zhao TL, Arimoto R, Wang YQ, Zhou ZJ. Sources of Asian dust and role of climate change versus desertification in Asian dust emission Geophys Res Lett. 2003;30. https://doi.org/10.1029/2003GL018206.

Zhao HL, Zhao ZY, Zhou RL, Zhang TH, Drake S. Desertification processes due to heavy grazing in sandy rangeland, Inner Mongolia. J Arid Environ. 2005;62(2): 309-19. https://doi.org/10.1016/j.jaridenv.2004.11.009.

\section{Publisher's Note}

Springer Nature remains neutral with regard to jurisdictional claims in published maps and institutional affiliations.

Ready to submit your research? Choose BMC and benefit from:

- fast, convenient online submission

- thorough peer review by experienced researchers in your field

- rapid publication on acceptance

- support for research data, including large and complex data types

- gold Open Access which fosters wider collaboration and increased citations

- maximum visibility for your research: over $100 \mathrm{M}$ website views per year

At BMC, research is always in progress.

Learn more biomedcentral.com/submissions 